\title{
THE QUEST FOR DEVELOPMENT IN AFRICA AND THE DILEMMA OF COMPETING CUL- TURAL PARADIGMS
}

Francis Offor, Ph.D

Department of Philosophy

University of Ibadan

Ibadan Nigeria

Email: offor66@yahoo.com

Abstract

This essay reopens the debate among African politicians and intellectuals concerning which paradigm is the most suitable for achieving the goals of development in Africa at this present moment of her history. Since the early 70s, African intellectuals and politicians have reflected on this problem and the highpoint of the debate was that only a synthesis of our traditional cultural elements with other relevant areas of foreign culture holds the prospects for achieving this goal. This essay however indicts this latest position as encouraging the hegemonisation of western cultural values as well as the marginalisation of those African states for which this paradigm is meant to serve as blueprint for development. The essay then identifies the need for the debate to transcend the basic assumptions underlying the major paradigms by preferring an approach that will not only guide against the continued marginalisation of African states, but that will at the same time ensure their effective participation in the development process currently going on across the globe. 
Keywords: Development, Culture, Modernization, Westernization, Regionalisation.

\section{Introduction}

The global development index categorises Africa as lagging behind every other continent in development and economic growth. Quite a number of states in the continent have in recent development reports been classified as failed or/and fragile states. This classification does not even spare some of the continent $\hat{Q}$ seemingly more promising and immensely endowed countries like Nigeria. The puzzle that the African dilemma presents is not borne out of this classification; rather the lacuna appears to hibernate in the apparent inability of the continent to respond positively to development paradigms - Michael Anyiam Ï Osigwe: 2006.

The above assertion by Michael Anyiam-

Osigwe re-affirms the claim of some intellectuals that the problem with Africa is not essentially that of a dearth of development options, but that it is more fundamentally that of how to ñrespond positivelyò to existing development paradigms, with a view to choosing among them, the one that is most appropriate for achieving the goals of development on the continent.

This essay relives the old discourse by interrogating three development paradigms that have been at the center of reflections and debates among African politicians and intellectuals since the early $70 \mathrm{~s}$, and attempts to explore further, the possibility of transcending the preliminary assumptions underlying these paradigms, with a view to evolving a more viable option 
requisite for Africaôs socio-political and economic development in this twenty first century.

Clothed in different slogans, African intellectuals have been in turgid turf over which option-among rejectionism, Kemalism and reformism-is the most viable for Africaôs development, and the highpoint of the debate is that African nations can attain meaningful development only be combining aspects of their traditional culture with relevant areas of foreign culture.

This essay however indicts this latest position as encouraging the hegemonisation of Western cultural values as well as the marginalisation of those African states for which this paradigm is meant to serve as blue print for development. The essay then identifies the need for the debate to transcend the basic assumptions underlying the three paradigms, by proffering an approach that will not only guide against the continued marginalisation of African states, but that will at the same time ensure their effective participation in the development process currently going on across the globe.

\section{The Debate: Rejectionism, Kemalism or Reform- ism?}

Since the early 70 s, disputations as well as divergent and antagonistic perspectives on what paradigm is the most appropriate for Africâ̂́ development have beleaguered the African socio-political and intellectual environments. The debate, which reached it peak in the early 1990s, focused on how nation states in Africa can attain meaningful development without compromising their identity. 
Generally scholars have viewed this issue from different perspectives, but the nucleus of their discussion is that éultureôcan be a veritable instrument for development. The reason for this emphasis on culture is because of the popularly held belief that the present crisis facing the continent is essentially a cultural crisis. The consensus of opinion is that the present crisis facing the continent is the long-term effect of the cultural dislocation suffered by the continent. That is, ñthe cultural discontinuity occasioned by Africa $\hat{Q}$ chequered history, a history which saw the displacement of the traditional world-view by an aliené paradigmò. (Uroh, 1998)

Cultural here is used in a very broad sense as the total way of life of a people. This includes the whole of technology, religion, politics, fashion; the whole distinctive complex of spiritual, material, intellectual, ethical and emotional features, as well as the integrated sum total of learned behaviour traits which are manifest and shared by members of a society. The consensus of opinion is that Africaôs cultural distortion by the Europeans, which now leaves Africa with an amorphous culture that is neither truly Western nor wholly African, is at the heart of Africaôs lingering and seemingly insoluble crisis of development.

This established link between Africaôs cultural dislocation and her present crisis confirm the intrinsic relationship that has existed overtime between culture and society and consequently, the positive role that culture can play in the development of a society (Oladipo,1999: 17). Although rejectionism, Kemalism 
and reformism are based on different assumptions as to what is possible or desirable, they all however revolve around a common theme, and that is how culture can be properly harnessed for the development of a society.

Let us start by rehearsing the familiar arguments of the various positions which culminated in the reformist thesis: that the best paradigm for development will be one that will combine the central values practices and institutions of a societyôs indigenous culture with those of other foreign nations.

The first response to the issue of how African nations can attain meaningful development came from the immediate post-colonial African leaders who saw the route to Africaôs development in the ñdiscovering of authentic African ideas and thought-system, uninfluenced by alien accretionô(Bodurin, 1985: xi). The argument here is that since the present crisis facing the African continent was occasioned by the dislodgement of African culture by the colonial administration, African nations can only transcend their present crisis by retracing their steps to discover ávhereôand why things went wrong and subsequently órighting the wrongô In doing this (the argument goes), African nations should closely and jealously guard their cultures from any foreign intrusion. This position has come to be referred to as ñcultural traditionalismò (Oladipo, 1995) or ñrejectionismò(Huntington, 1997: 74).

The second response to the issue of how African nations can attain meaningful development is from those who are of the view that African traditional cultures have become anachronistic, and that it is no 
longer plausible to rely on traditional cultures for solutions to Africâ̂s myriad problems. They therefore urge African nations to embrace Western culture in its totality and to throw overboard or modify practically beyond recognition, the traditional African value system. The titles ñ culture surrenderò (Oladipo, 1995) or ñKemalismò (Huntington, 1997: 73) is used to describe the above position.

The third response to the problem of Africa $\hat{s}$ development is from those who argue that Africa would not develop simply by relying entirely on its tradition culture, nor would it develop by totally abandoning its past cultural heritage for those of the West. What this position recommends is a synthesis of the cultural worldviews earlier discussed. This position has come to be known as ñcultural syncretismò or reformismò (Huntingon,1997: 74).

Obviously, rejectionism and kemalism have their own merits, and of course demerits. As Segun Oladipo rightly notes, ñcultural surrender is as flawed as the kind of traditionalism which it urges us to rejectò (Oladipo, 1995), for to assert that nothing more or less good can be retrieved from traditional culture in the effort to forge a suitable vision of development for Africa (as the advocates of Kemalism have argued) does have a number of negative consequences. First, such a position shows a lack of confidence in Africa and all that she stands for, and so plays down on the possibility of Africa countries achieving significant scientific and technological development by looking inward. The position implies further that African nations should only 
avail themselves of Western development models in all situations, even where traditional African alternatives may provide useful insights for particular situations. On the other hand however, rejectionism results, as it were, from extreme patriotism and so refuses to appreciate certain facts about human kind. It fails to realize that while Africans are unlike others in certain aspects of their culture, they however also share with others, other aspects of culture which establish their identity with others, as members of the human species. Hence to the reformists, neither cultural rejectionism nor Kemalism holds a promise for an enduring future for Africa. The reformists suggest instead that the route to Africâิ development lies in the blending of elements of her traditional culture with those of foreign countries. This position brings into perspective, the dynamic nature, not only of man, culture and the society, but also of the problems confronting modern African nations. Some of the problems facing modern African states are of such magnitude that they exceed the capacity of any single African society to successfully address them through the idea of local culture operating in isolation, while some other problems even traverse national boundaries. Findings solutions to such problems would in the opinion of the reformists, require co-operating and dealing with peoples, values, bias, views and ideas from other lands (Baradat, 1997: xi).

Against the backdrop that accepting the full force of Western influence does have the negative consequence of fueling the present identity crisis on the African continent, the reformists outlined how African nations can embrace foreign culture without any dimi- 
nution of identity. The distinctions made by professors Kwasi Wiredu and Youichi Ito are relevant in this regard. In his Problems in Africa's Self Definition in the Contemporary World, Wiredu distinguishes between those elements of culture which have no essential bearing on questions of human well-being or universal truth, and areas of human experience in which the effects of cultural difference could conceivably be eliminated through the peaceful give and take among cultures. He then argues that:
A culture can shed off many of its traits and gather foreign accretions without sacrificing its identity, provided that it does not lose its contingent features (Wiredu, 1992).

Wireduôs distinction corresponds with the distinction earlier drawn by the Japanese Scholar, Youichi Ito, between áhe competitiveôand áhe non competitiveôsectors of culture. Ito describes the competitive sector of culture as comprising those aspects of civilization, which people can easily compare, to determine which is superior, or inferior such as ôndustrial strengthô áconomic scaleô and áechnologyô while the non competitive sector includes aspects of human culture and civilization in which competition is not involved such as languageô religion, ideology, óalue systemô way of life, way of thinking, music, fine arts, stage arts and so on. To Ito, a country can shed off some aspects of her culture and gather foreign ones 
without any diminution of identity, provided that this cultural exchange takes place only in the competitive sector. This is because in the competitive sector of human culture and civilization according to Ito, such classificatory labels like Westernization or Easternisation do not apply. This is how Ito puts it:

\author{
What looks like Westernization or East- \\ ernisation is usually nothing but ad- \\ vancement, which permits nations to \\ catch up with superior or more devel- \\ oped nations in the competitive sector \\ (Ito, 1988: 140).
}

To this end, he interpreted Japanôs economic, technological and military build up, not as Westernization but as simply an attempt to increase its ranking with regard to its international competitors. The position of the reformists which is ably presented here by Wiredu and Ito is that the route to Africaố development lies in a conscious and reflective blending of elements of her traditional culture which are still conducive to human development, with aspects of the cultural heritage of other lands which are existentially beneficial (Oladipo: 1995).

\title{
THE GLOBAL ORDER AND THE CHALLENGES OF REFORMISM
}

We agree in part with the reformist, that for Africa to participate effectively in the development process and thereby partake in using mankindôs accumu- 
lated wisdom and experience in solving her myriad problems, there should be greater international cooperation. For it is in the process of such co-operation that countries influence and learn form one another, and this has been the history of the development of human culture and civilization. However, if the relationship between countries is symmetrical, in the sense that countries influence and learn from one another in equal proportion, then, one can almost predict the outcome of such relationships as enriching the cultures and enhancing the development of all the countries involved. But when ñforeign influence is overwhelming, beyond the control of the receiving country, or one way for a long period of time, psychologically delicate problems emergeò(Ito, 1988: 137). These psychological problems manifest, first in the feeling of cultural inferiority, resulting in a loss of ćultural integrity, imagination, creativity and energyôand then leading eventually to a complete cultural and social collapse. And this is exactly what the prevailing conditions in the world today have offered African nations in their relationship with the West.

In the contemporary world order, nations are not presented with what Irele aptly describes as ñequality of opportunityò in their competition with one another.

What the condition of ñequality of opportunityò implies is that each culture should be put on a rough equal basis and that there should be a sort of procedural justice that treats culture fairly as they compete (Irele, 1998: 112). $\mathrm{Bt}$ as Kazuo Ogura rightly observes, there is (at the moment) no international tally-taker or global enforcer that can ensure that all parties are considered equal partners 
and receive fair treatment as they compete (Ogura,1988: 34). The implication of this lack of áquality of opportunityôis that the outcome of any cultural intercourse between Western and African nations will be such that will ensure that Western nation enjoy a unilateral and hegemonic influence over African nations. The final products of such cultural dialogue are bound to be problematic for Africâิ digestion of them.

Besides the lack of equality of opportunity, the socio-political institutions on ground in most African states today are still those inherited colonial structures of Western origin, which were originally set up by the colonial master to displace the local cultures and values. These structures therefore are bound to remain hostile to any arrangement that would mix Western cultures with African traditional values, which they originally came to displace. What we are saying in essence is that what we have today, as institutions and structures in African nations are not in any significant way different from what the colonial administrators put in place for the management of colonial territories. And since the colonial politics and administration were essentially geared towards the exploitation of the resources of the colonized society, the colonial institutions were meant primarily to enhance the attainment of this bizarre goal. No wonder then these institutions ñhave been inadequate for the achievement of the goals of post colonial developmentò (Oladipo,1998: 111), and it is also our contention, that such institutions will be inadequate for any vision of development that would mix Western cultures with African traditional practice. 
Finally, the fact that modern conception of álevelopmentôis conventionally Western will mean that in the event of any intercourse between Western culture and those of African nations, those aspects of Western culture, which are reminiscent of Western models of development, are bound to be over-valued and subsequently embraced incautiously.

The point so far made against reformism as a paradigm of development is that given the prevailing conditions in the world today, and given also the nature of post colonial state institutions in Africa as well as the modern day conception of development which is predominantly Western, African nations are not suitably disposed to any cultural interchange with the West, and as recent experiences have shown in the areas of Politics, Economy and Information Communication Technology, African values are likely to remain subjugated and overwhelmed by Western cultural values. It follows therefore that reformism, as a paradigm of development has the potential for fueling the present cultural identity crisis on the African continent.

However, running through all three paradigms is the view that development is conterminous with modernization and that modernization means Westernization. On this view, the idea of development would revolve round the issue of whether or not and to what extent modernization and Westernization are desirable. For óejectionismôboth modernization and Westernization are undesirable and it is possible for a society to reject both and still develop. For Kemalism, the indigenous culture is incompatible with modernization and so 
must be abandoned, but for a society to successfully modernize, it must fully westernize because westernization is indispensable to achieving modernization. For reformism, modernization is desirable, but without substantial westernization. Instead, reformism attempts to combine modernization with those central values, practice and institutions of a societyô indigenous culture.

The point however is that modernization does not necessarily mean westernization and none of them is sine qua non to development. The idea of westernization means, to make or become like the people of Europe or American in adopting their custom, practices, institutions and ideas. Westernization therefore involves absorbing substantial elements of those central practices, institutions and ideas of Western culture. Westernization predates modernization, for those societies of the west which are today the prototypes of modernization were for many years óvesternôbefore they later became ómodernizedô in the same way as we have many societies moving into modernization without becoming Western. On the other hand, the Chambers Dictionary has the following entries on its list of definitions for development.

To bring out what is latent or potential in.

To advance through successive stage to a higher, more complex or more fully grown stage.

There is no doubt that every human society is imbued with potentials and that all societies are by nature dynamic. In view of this, and going by the definitions above, a society can chart its own course of devel- 
opment, which may differ substantially from the three prototypical paths enumerated above. But unfortunately, according to Ali Mazrui, African states have up till now moved up the development path inversely, through a ñpainful process of cultural westernization without technical modernizationò(Huntington, 1997: 75). It follows therefore that if modernization were prelude to development, then African states have been missing the mark! How then do African nations get out of this crisis and still make themselves relevant in the emerging world system in which globalisation is the defining feature?

\section{CONCLUSION: MEETING THE CHALLENGES OF DEVELOPMENT IN A GLOB ALISING WORLD}

The phenomenon of globalisation, though has its positive aspects, has nevertheless come to be viewed negatively by many as a threat to national and local cultures and the sanctity of tradition. It is further accused of not only evolving new forms of authoritarianism and patriarchy but of also heralding:
A new age of imperialism in which na- tional, regional and global asymmetries characterized by social injustices and un- equal exchange are much more pro- nounced and pernicious than was the case before (Adele, 1999: 31).

The asymmetries described above weigh more against the poor underdeveloped states from the Southern 
hemisphere, most especially those from Africa (Owolabi, 2001: 71-72; Kellner: 1998: 32; Castells, 1998: 83). In fact, globalisation is said not only to undermine states from this part of the world, it is even feared by some that such states might be displaced completely in the nearest future by major global corporations and institutions powered by the West. Such states are allegedly ñtrapped within webs of global interconnectedness permeated by quasi supranational, intergovernmental and transnational forcesò (Held, 1995: 92), thus making it impossible for them to play any major or decisive role in matters that will ultimately affect them.

The dangerous implication of this trend is that the capacity of such states to act independently in the articulation of international or even domestic policy objectives faces gradual erosion. Given these constraints, how do states in Africa meet the challenges of development and still make themselves relevant within the context of a globalising world?

As regard the way out of the present imbroglio, it has become very clear that states in Africa cannot confront individually, given the realities on ground at the moment, the big monopolies of the global system. Even more sad are the various dimensions of conflicts inflicted upon the continent by Africans themselves. And contrary to the trend in other continents where there are various attempts at integration, most especially at the regional levels, African countries are, as a result of self-inflicted crises, breaking up into smaller pieces, without realizing the opportunity this has cre- 
ated for their continued marginalisation by the dominant nations of the global system.

One way out of this problem therefore is for African countries to intensify efforts at regional integration, and then harness properly, the benefits of such integration for development purposes. Two different views of regionalisation can be distinguished here. The first view is that which looks at regions as an intermediary stage between the nation state and the global system. In this perspective:

Regionalisation is not looked at as the region delinking from the global system, but on the opposite, the region being a member of the global system, participating in the global system (Amin, 1998:

172).

This sort of regionalisation however, merely associates the center with the periphery of the global system, thereby giving room for the participatory countries to utilize any possible advantage but without necessarily challenging ñthe global liberal view of the global systemò. The North America Free Trade Association (NAFTA), which associates Mexico (a developing country) to the United States and Canada, is a typical example of this type of regionalisation. This is not the type of regionalisation we are recommending for African states.

The second view of regionalisation is that which arises in recognition of the fact that the countries and regions are very unequally developed and therefore sees 
the need to reshape the global system with a view to opening avenues to develop the least developed of these areas (Amin, 1998: 172). This arrangement would enable regions to challenge at the regional level and for the regional organisation, what Samir Amin has called ñthe five monopolies of the centerò, viz: the monopoly of technology: the monopoly of finance: the monopoly of assets and wastes of natural resources; the monopoly of communication, culture and politics; and the monopoly of mass destruction armament, nuclear and others (Amin, 1998: 172-173). This, for us is the concept of regionalisation Africa needs. It is a concept of regionalisation of a polycentric world and it is only by this means that African nations (as a collective) can surmount their developmental problems and challenge the hegemonic influence of the big monopolies of the global system. In this way, Africa would have responded to Professor Anyaôs challenge of designing and putting in place ña strategy of development founded on knowledge and experience and inter-linked with the global arrangements, (but), on terms defined by African conditions and traditionsò (Anya, 1998: 26). 


\section{References}

Amin, S., ñAfrica, Return to Pan Africanism: Interview with Samir Amin by Chris Urohò, in Chris Uroh (ed) African and the Challenge of Development (Hope Publications, 1998).

Anyiam- Osigwe, M., ñPhilosophy and Development Paradigms: Towards a Requisite Synthesis for Africaôs Socio-Political and Economic Transformationò Being a speech delivered at the eight session of the Emmanuel Onyechere Osigwe Anyiam-Osigwe lecture series held at the Nigerian Institute for International Affairs (NIIA), Lagos Nigeria, November, 2006.

Anya, O. A., ñKnowledge and Experience; Biology and the Evolution of a New Paradigm for Africâิ Sustainable Developmentò in Olusegun Oladipo (ed.) Remaking African: Challenges of the Twenty-First Century (Ibadan: Hope publications, 1998).

Baradat, P. L., Political Ideologies. Their Origins and Impact (New Jersey: Prentice Hall, 1997).

Bodunrin, P.O., (ed.) Philosophy in Africa: Trends and perspectives (Ile-Ife: University of Ife Press, 1985).

Castells, M., The End of Millenium (Cambridge: Basic Blackwell, 1998).

Held, D., Democracy and the Global Order (U K: Polity Press, 1995).

Huntington, S. P., The Clash of Civilization and the Remarking of the World Order (New York: Touchstone. 1997). 
Ito, Y., ñGlobal Communication and Cultural Identity: An East Asian Perspectiveò in Hellmut Schutte (ed.) Strategic Issues in Information Technology: International Implications for Decision Makers (English: Pergamon Into Tech. 1988).

Irele, D., Introduction to Political Philosophy (Ibadan: University Press, 1998).

Jinadu, A., ñAfrica and Globalised Political Scienceò in Comet Newspaper, Nigeria, $5^{\text {th }}$ July, 1999.

Kellner, D., ñGlobalisation and the Postmodern Turnò in Roland Axtman (ed.), Globalisation and Europe, Theoretical and Empirical Investigations (London: Pinter, 1998).

Ogura, K., ñnformation Decision and National Decision Makersò in Hellmut Schutte (ed.) Strategic Issues in Information Technology: International Implications for Decision Makers (English: Pergamon Into Tech., 1988).

Oladipo, O., ñContemporary African Philosophy: Issues, Tasks and Problemsò a paper presented at the international Conference on African Philosophy, Bodija, Ibadan, Nigeria, 1993.

Oladipo, O., ñModernization and the Search for Community in Africa: Crises and Condition of Changeò In Olusegun Oladipo (ed) Remarking Africa: Challenges of the Twenty-First Century (Ibadan: Hope publications, 1998).

Oladipo, O., r̃Philosophy and Cultureò in Ayo Fadahunsi (ed) Philosophy and Society: An Introdution for Beginners (Ibadan: Hope Publications 1999). 
Owolabi, K. A., ñGlobalisation, Americanisation and Western Imperialismò Journal of Social Development in Africa, Vol. 16, No. 2, pp.71-91.

Uroh, C., ñCultural Syncretism in Africaò Future Bulletin vol. 24, No. 1 (Bacholod City: Philippines World Future Studies Federation, 1998).

Wiredu, K., r̃Problems in Africaô Self Definition in the Contemporary Worldò in Person and Community: Ghanaian Philosophical Studies Vol. 1, series 11, 1992. 